\title{
Pharmacological interventions in acute respiratory distress syndrome
}

\author{
Antoine Roch ${ }^{1,2,3^{*}}$, Sami Hraiech ${ }^{1,2}$, Stéphanie Dizier ${ }^{2}$ and Laurent Papazian ${ }^{1,2}$
}

\begin{abstract}
Pharmacological interventions are commonly considered in acute respiratory distress syndrome (ARDS) patients. Inhaled nitric oxide (iNO) and neuromuscular blockers (NMBs) are used in patients with severe hypoxemia. No outcome benefit has been observed with the systematic use of iNO. However, a sometimes important improvement in oxygenation can occur shortly after starting administration. Therefore, its ease of use and its good tolerance justify iNO optionally combined with almitirne as a rescue therapy on a trial basis. Recent data from the literature support the use of a 48-h infusion of $\mathrm{NMBs}$ in patients with a $\mathrm{PaO}_{2}$ to $\mathrm{FiO}_{2}$ ratio $<120 \mathrm{mmHg}$. No strong evidence exists on the increase of ICU-acquired paresis after a short course of NMBs. Fluid management with the goal to obtain zero fluid balance in ARDS patients without shock or renal failure significantly increases the number of days without mechanical ventilation. On the other hand, patients with hemodynamic failure must receive early and adapted fluid resuscitation. Liberal and conservative fluid strategies therefore are complementary and should ideally follow each other in time in the same patient whose hemodynamic state progressively stabilizes. At present, albumin treatment does not appear to be justified for limitation of pulmonary edema and respiratory morbidity. Aerosolized $\beta 2$-agonists do not improve outcome in patients with ARDS and one study strongly suggests that intravenous salbutamol may worsen outcome in those patients. The early use of high doses of corticosteroids for the prevention of ARDS in septic shock patients or in patients with confirmed ARDS significantly reduced the duration of mechanical ventilation but had no effect or even increased mortality. In patients with persistent ARDS after 7 to 28 days, a randomized trial showed no reduction in mortality with moderate doses of corticosteroids but an increased $\mathrm{PaO}_{2}$ to $\mathrm{FiO}_{2}$ ratio and thoracopulmonary compliance were found, as well as shorter durations of mechanical ventilation and of ICU stay. Conflicting data exist on the interest of low doses of corticosteroids ( $200 \mathrm{mg} /$ day of hydrocortisone) in ARDS patients. In the context of a persistent ARDS with histological proof of fibroproliferation, a corticosteroid treatment with a progressive decrease of doses can be proposed.
\end{abstract}

Keywords: Acute respiratory distress syndrome; Nitric oxide; Neuromuscular blockers; Fluids; Albumin; Corticosteroids; Hypoxemia; Fibrosis; Rescue therapy; Outcome

\section{Review Introduction}

Dysregulated inflammation, accumulation and activity of leukocytes and platelets, uncontrolled activation of coagulation and altered permeability of alveolar endothelial and epithelial barriers leading to pulmonary edema are key points in the pathophysiology of acute lung injury and acute respiratory distress syndrome (ARDS) [1]. ARDS results in impaired gas exchange and hypoxemic respiratory

\footnotetext{
* Correspondence: antoine.roch@ap-hm.fr

'URMITE, UM63, CNRS 7278, Aix Marseille Université, IRD 198, Inserm 1095, 13005, Marseille, France

${ }^{2}$ APHM, CHU Nord, Réanimation, 13015, Marseille, France

Full list of author information is available at the end of the article
}

failure, which can be refractory and life-threatening [2]. Besides ventilatory support, pharmacological interventions are commonly considered throughout the course of ARDS. Some of these interventions affect supportive care, such as fluid management or neuromuscular blockers (NMBs), whereas others are focused on recovery from hypoxemia or have been studied in patients with persistent ARDS. The present review will summarize clinical results and practical aspects of pharmacological interventions, which are more largely used by clinicians. The current evidence about inhaled nitric oxide, almitrine, NMBs, fluid management, $\beta 2$-agonists, and corticosteroids will be addressed successively.

\section{实 Springer}




\section{Inhaled nitric oxide and almitrine}

Inhaled nitric oxide (iNO) selectively vasodilates the pulmonary vasculature in ventilated alveoli, which improves ventilation-perfusion matching and hypoxemia and lowers pulmonary arterial pressure. Its administration via the inhaled route and its very short half-life minimize systemic effects (i.e., hypotension) [3]. In randomized, clinical trials (RCTs) [4-8], iNO was associated with a transient improvement in oxygenation in adults with ARDS. However, no survival benefit or reduction in ventilator-free days has been observed. In a systematic review and meta-analysis of patients with acute lung injury (ALI) or ARDS from 12 trials, iNO was associated with modest improvements in oxygenation $\left(13 \%\right.$ of increase in $\mathrm{PaO}_{2}$ to $\mathrm{FiO}_{2}$ ratio until day 3-4 of administration), no effect on mean pulmonary artery pressure, and no effect on survival or duration of mechanical ventilation [9]. However, available RCTs do not resolve the question of whether iNO leads to any clinically significant benefits in certain subgroups of patients, such as those with severe hypoxemia not responding to conventional treatment [10]. In this sense, iNO is frequently used as a rescue therapy. For example, iNO was used during ICU stay in respectively $30 \%$ and $20 \%$ of ARDS patients included in two large RCTs [11,12]. Moreover, iNO was used for refractory hypoxemia in 32\% of the patients subsequently treated with ECMO during the $2009 \mathrm{H} 1 \mathrm{~N} 1$ pandemic in Australia/New Zealand [13]. When defining a positive response as an increase of at least $20 \%$ of $\mathrm{PaO}_{2}$ to $\mathrm{FiO}_{2}$ ratio, about half of patients are responders to iNO $[6,14]$. However, because improvement in oxygenation can be dramatic in the setting of life-threatening hypoxemia and because no radiological or physiological predictive factor of response has been identified [15,16], its use can be supported in this setting on a trial basis, what may buy time for the institution of other means of support. Clinically significant improvement in oxygenation following initiation of iNO should be demonstrated within the first hour of therapy to justify continued use. A maximal oxygenation benefit typically occurs with doses as low as 0.1 to $2 \mathrm{ppm}$ [17] and always with doses of less than $20 \mathrm{ppm}$ [18]. Worsening of oxygenation has been frequently documented with doses above $20 \mathrm{ppm}$ [19] or even above $10 \mathrm{ppm}$ [18]. Moreover, the dose-response curve has been shown to shift progressively to the left in patients receiving iNO continuously for several days [20], implying that the optimal dose of iNO must be determined by titration against the therapeutic target in each patient at least each day. INO has additive effects on oxygenation with prone positioning [21] and with high frequency oscillatory ventilation [22]. The effect of iNO is not influenced by the administration of vasopressive agents, such as norepinephrine [23,24], but iNO has additive effects on oxygenation with almitrine, a selective pulmonary vasoconstrictor $[25,26]$. A progressive iNO weaning on several hours is suggested due to the risk of oxygenation worsening, pulmonary artery pressure increase, and hemodynamic collapse in case of sudden discontinuation [14]. INO may contribute to the formation of cytotoxic reactive nitrogen species and reactive oxygen species, especially when administered with high concentrations of oxygen [27]. This is minimized by limiting $\mathrm{FiO}_{2}$, by introducing iNO into the inspiratory limb of the ventilator tubing as near to the patient as possible [28] and by synchronizing injection of iNO with inspiration [29]. Up to $40 \mathrm{ppm}$ of iNO should not cause methemoglobinemia in adults in the absence of methemoglobin reductase deficiency [30].

Experimentally, almitrine increases hypoxic pulmonary vasoconstriction, except where strong vasoconstriction is already present [31]. In patients with ARDS, almitrine causes a redistribution of blood flow to well-ventilated areas and improves oxygenation [32] while increasing pulmonary artery pressure [33-35]. It is suggested that low-dose almitrine enhances hypoxic pulmonary vasoconstriction, whereas at high doses $(>20 \mu \mathrm{g} / \mathrm{kg} / \mathrm{min})$, it would induce diffuse and inefficient vasoconstriction [36,37]. In this sense, dosages of 2 to $4 \mu \mathrm{g} / \mathrm{kg} / \mathrm{min}$ have been shown to be optimal in most patients [34,38,39]. Almitrine has additive effects on oxygenation with iNO in approximately two thirds of iNO responders [25,38]. However, some patients may be responders to almitrine while they did not respond to iNO [25,38]. The effectiveness of almitrine on oxygenation often is reduced in septic patients receiving norepinephrine $[23,24]$. Therefore, the use of higher doses of almitrine $(16 \mu \mathrm{g} / \mathrm{kg} / \mathrm{min})$ may produce further improvement in oxygenation in patients receiving norepinephrine if they are responders to iNO [26]. The efficiency of prolonged administration of almitrine has not been evaluated. Because of an increased pulmonary artery pressure, high doses of almitrine $(16 \mu \mathrm{g} / \mathrm{kg} / \mathrm{min})$ may result in reduced right ventricular ejection fraction [40]. Therefore, almitrine is not recommended in patients with severe pulmonary hypertension or acute cor pulmonale. The prolonged administration of almitrine has been involved in peripheral neuropathies in COPD patients [41,42]. This complication was usually associated with circulating levels $>400 \mathrm{ng} / \mathrm{ml}$. While intravenous administration of $16 \mu \mathrm{g} / \mathrm{kg} / \mathrm{min}$ of almitrine in patients with ARDS was associated with levels $>400 \mathrm{ng} / \mathrm{ml}$ in 16 of 17 patients, a dosage of $4 \mu \mathrm{g} / \mathrm{kg} / \mathrm{min}$ resulted in high levels in only one patient [32], suggesting that this dosage would be safe on the neurological function. The almitrine also may have liver toxicity [43]. A reversible and dose-dependent increase in lactate level associated with impaired liver function was observed in 8 of 25 patients in the first 24 hours of administration of 2 of $8 \mu \mathrm{g} / \mathrm{kg} / \mathrm{min}$ of almitrine [43]. As for iNO, a frequent and quick effect on oxygenation supports the optional use of almitrine in patients with very severe hypoxemia on a trial basis, until the institution of other means of support. The absence 
of response to the administration of $0.5 \mathrm{mg} / \mathrm{kg}$ in 30 minutes does not justify any continued administration.

\section{Neuromuscular blockers}

Several studies have reported the frequent use of neuromuscular blockers (NMBs) in severe ARDS patients, reaching $40-50 \%$ in several recent RCTs $[12,44,45]$. One of the main reasons to justify the use of NMBs in ARDS is facilitation of mechanical ventilation and control of patient/ventilator asynchrony. Arroliga et al. [46] found that the factors associated with a more frequent NMB use were mainly related to the severity of the lung disease, such as the presence of ARDS criteria, high plateau pressures, and also by the use of prone positioning, high PEEP levels, or nonconventional modes of ventilation, such as high-frequency oscillatory ventilation [47]. Several recent studies have shown an improvement in oxygenation with the use of NMBs in ARDS patients [11,48-50]. In the studies by Gainner et al. [49] and Forel et al. [50], patients randomized to the NMB group had a higher $\mathrm{PaO}_{2}$ to $\mathrm{FiO}_{2}$ ratio at 48, 96, and $120 \mathrm{~h}$ after randomization. In contrast, there was no change in the $\mathrm{PaO}_{2}$ to $\mathrm{FiO}_{2}$ ratio $1 \mathrm{~h}$ after randomization in the NMB group. The decrease in plateau pressure and PEEP requirements during the 120-h study period were more marked in the NMB group. Recently, a larger RCT confirmed these results [11], showing a $\mathrm{PaO}_{2}$ to $\mathrm{FiO}_{2}$ ratio on day 7 higher in patients receiving a 48-h continuous cisatracurium infusion than in the control group. In this multicenter, double-blind trial [11], 339 patients presenting with severe ARDS within the previous $48 \mathrm{~h}$ (i.e., $\mathrm{PaO}_{2}$ to $\mathrm{FiO}_{2}$ ratio $<150 \mathrm{mmHg}$ with PEEP of at least $5 \mathrm{~cm} \mathrm{H} \mathrm{H}_{2} \mathrm{O}$ ) were randomly assigned to receive either cisatracurium besylate (bolus of $15 \mathrm{mg}$ i.v., then $37.5 \mathrm{mg} / \mathrm{h}$ infusion for $48 \mathrm{~h}$ ) or placebo for $48 \mathrm{~h}$. The group of patients treated with cisatracurium had a higher adjusted 90-day survival rate compared with those who received placebo (hazards ratio (HR) 0.68 ; $95 \%$ confidence interval (CI) $0.48-0.98 ; p=0.04$ ). It is noteworthy that the beneficial effect of cisatracurium on mortality was limited to the patients presenting a $\mathrm{PaO}_{2}$ to $\mathrm{FiO}_{2}$ ratio of less than $120 \mathrm{mmHg}$. These results were recently confirmed in a meta-analysis [51]. The observed improvements in mortality and gas exchange raise the question of the mechanisms involved. The positive effects of NMBs could be related to a decrease in ventilator induced lung injury, as suggested by the decreased incidence of barotrauma and pneumothoraces in the cisatracurium group [11]. NMBs also could reinforce the beneficial effect of lung-protective mechanical ventilation in patients with ARDS through a reduction in biotrauma. Forel et al. [50] showed that after $48 \mathrm{~h}$ of NMB infusion in ARDS patients, pulmonary concentrations of IL-1b, IL-6, and IL-8, as well as serum concentrations of IL-1b and IL-6 were lower than in the control group. This hypothesis is reinforced by the observed decrease in the number of organ failures in the cisatracurium group of the ACURASYS study [11], possibly as a result of less biotrauma. NMBs also could help to avoid patient-ventilator dyssynchrony and limit end-expiratory collapse by inhibiting active expiration, limiting derecruitment, and maintaining PEEP [52]. Moreover, in some patients, inspiratory efforts could lead to global or regional increases in transpulmonary pressure that can be deleterious [53]. These recent data from the literature provide a strong argument for beneficial effects of NMBs during the early phase of severe ARDS and support the use of a 48-h infusion of cisatracurium in patients with more hypoxemic ARDS (particularly with a $\mathrm{PaO}_{2}$ to $\mathrm{FiO}_{2}$ ratio $<120 \mathrm{mmHg}$ ). However, risks of using NMBs have been reported and have resulted in controversy regarding the use of these agents in ARDS patients. The incidence of ICU-acquired weakness is $34-60 \%$ in patients with ARDS [54]. Administration of NMBs does not appear to be an independent risk factor for ICU-acquired weakness [55] if they are not given with corticosteroids or in patients with hyperglycemia [56]. In the ACURASYS study [11], the incidence of ICU-acquired paresis was not higher in patients receiving NMBs than in the control group. Hypersensitivity reactions occurring after administration of NMBs are a major cause for concern. A recent survey [57] of hypersensitivity reactions observed during anesthesia showed that cisatracurium was involved in 5.9\% of anaphylaxis episodes. Finally, paralyzing patients highlights the problem of inadequate sedation [58].

\section{Fluid management}

In the early phase of ARDS, an associated septic state is usually responsible for hypovolemia. At this stage, hemodynamic optimization by early and adapted fluid loading has proven its prognostic value [59] and a fluid restriction strategy can result in hemodynamic aggravation and dysfunctions of associated organs, determining the mortality of patients presenting ARDS [60]. Nevertheless, ARDS is particularly characterized by pulmonary edema due to an increase in pulmonary capillary permeability. Edema has an impact on respiratory function at several levels: decrease in compliance, hypoxemia, alteration of surfactant, pulmonary hypertension [61]. Thus, any attempt to reduce edema potentially can have beneficial effects on respiratory function and eventually outcome. Several studies have suggested a prognostic role of the quantity of lung water in ARDS patients [62-64]. Moreover, large cohort studies have shown that positive fluid balance was associated with higher mortality in patients with acute lung injury or ARDS [65] or in patients with septic shock [66]. However, to date, no study evaluated strategies specifically designed to reduce lung water content and to evaluate their prognostic impact. Fluid restriction that is more or less associated with a diuretic treatment makes possible to 
reduce both pulmonary capillary pressure and central venous pressure (CVP) due to lung edema resorption through an improvement in venous return. A randomized, multicenter study evaluated a strategy of fluid restriction that was more or less associated with diuretic treatment prescribed in the absence of hypotension and renal failure in patients with acute lung injury or ARDS [67]. Patients were included in the study approximately 48 hours after admission to the ICU. The decision to submit patients to fluid loading or diuretic treatment depended on the presence of oliguria and the level of CVP. Schematically, the purpose was to obtain a CVP of $8 \mathrm{mmHg}$ or less in the "conservative-strategy" group or $14 \mathrm{mmHg}$ in the "liberalstrategy" group. The protocol was applied for 7 days after inclusion of the patient but was not applied in cases of hypotension. The conservative strategy resulted in zero fluid in 7 days, whereas the fluid results in the liberalstrategy were +6 liters over 7 days. The conservative strategy discreetly improved oxygenation in patients and increased the number of days without ventilation (14.6 \pm 0.5 vs. $12 \pm 0.5, p<0.001)$ but did not influence mortality at 60 days, which was the principal purpose of the study.

This study confirmed the impression that limiting the fluid intake of patients with isolated respiratory failure can limit respiratory morbidity without aggravating other organ dysfunctions. However, the exclusion of hemodynamically unstable patients or patients with renal failure makes impossible to generalize these results or to create a "gold standard" for management of the fluid status of every ARDS patient. In addition, the absence of an effect on mortality reminds us that the management of fluid intake in ICU patients does not boil down to being liberal or conservative. It is only once the initial phase of hemodynamic instability has passed that a reasonable policy of fluid intake aimed at zero fluid can contribute to reducing the duration of ventilation and ICU stay [68]. The importance of a "biphase" fluid strategy was recently illustrated by a retrospective study that included 212 patients presenting acute lung injury complicating septic shock [69].

In this study, the nonperformance of early adapted fluid administration and the absence of a negative fluid balance during a minimum of the first 2 consecutive days within the 7 days following the occurrence of septic shock were independent mortality factors in multivariate analysis. Along these lines, the Surviving Sepsis Campaign [70] recommends a conservative fluid strategy for patients with established ARDS who do not have evidence of tissue hypoperfusion. From a hemodynamic point of view, in case of a decrease in plasmatic oncotic pressure, which is clinically illustrated by hypoprotidemia/hypoalbuminemia, pulmonary edema forms at a lower hydrostatic pressure because the oncotic pressure gradient between plasma and the interstitium decreases [71]. Therefore, hypoprotidemia frequently observed in ICU patients facilitates the development of hydrostatic pulmonary edema. However, the importance of oncotic pressure in the limitation of flux is only conceivable if the barrier is intact. In case of endothelial lesions, an interstitial edema will be all the richer in proteins than the plasma, theoretically limiting the interest of increasing the plasmatic oncotic pressure [72]. The interest of a strategy of diuretic treatment associated with albumin filling in ARDS patients with a protidemia inferior to $50 \mathrm{~g} / \mathrm{l}$ has been investigated by Martin et al. [73,74]. In the most recent study [74], 40 patients were randomized receiving either furosemide alone or furosemide and albumin $(75 \mathrm{~g} / \mathrm{d})$ for 3 days. When protidemia was superior to $80 \mathrm{~g} / \mathrm{l}$ in the treated group, albumin was replaced with a placebo. Albuminemia increased by $13 \mathrm{~g} / \mathrm{l}$ in the albumin + furosemide group, reaching $30 \mathrm{~g} / \mathrm{l}$ at the end of treatment and increased by $3 \mathrm{~g} / \mathrm{l}$ in the furosemide alone group, reaching $20 \mathrm{~g} / \mathrm{l}$ at the end of treatment. The effects can be summarized by a discrete improvement in oxygenation when albumin was associated with diuretic treatment compared with diuretic treatment alone.

A large, randomized study [75] demonstrated that volume therapy using albumin was equivalent to volume therapy using saline in ICU patients. At this time, the very limited clinical data do not make it possible to recommend the administration of albumin with the goal to improve pulmonary function and respiratory morbidity in ARDS patients. Two recent RCTs evaluated the effects of albumin in septic patients $[76,77]$. In the first, conducted in France [76], 798 patients with septic shock were randomized to receive either $300 \mathrm{ml}$ of $20 \%$ albumin per day for 3 days or the same amount of saline. Neither mortality at day 28 nor the respiratory outcome was different between groups. The second was conducted in Italy [77] and included 1,800 patients with severe sepsis or septic shock. Patients were randomized to receive crystalloids and albumin to maintain albumin level $>30 \mathrm{~g} / \mathrm{l}$ until day 28 or crystalloids alone. Although day- 90 mortality was not different between groups, the use of albumin in the subgroup of patients with septic shock was associated with a reduction of mortality.

No large study investigated the interest of using hydroxyethylstrach (HES) for fluid loading in ARDS patients. However, considering the increased risk of renal dysfunction associated with their use [78], especially in septic patients [79], they cannot be recommended in ARDS patients. The use of hyperosmolar filling solutions, such as hypertonic saline, could have the advantage, due to the limited amount of fluid administered, of limiting the development of pulmonary edema in case of an increase in the alveolocapillary barrier. Experimental studies have provided conflicting results on this point [80-82]. In clinical practice, the potential interest of hypertonic resuscitation has been 
investigated in patients with traumatic hypovolemic shock. In a recent randomized study that included 853 patients, fluid loading with hypertonic saline or hypertonic saline/ dextran neither reduced mortality nor prevented ARDS occurrence compared with normal saline resuscitation [83].

\section{$\boldsymbol{\beta} 2$-agonists}

Recovery from ARDS requires that the pulmonary edema resolve [84]. The resolution of alveolar edema is driven by active transport of sodium and chloride ions from the luminal space across alveolar epithelial cells, creating an osmotic gradient for the reabsorption of water. Despite severe epithelial lesions, alveolar clearance is usually pharmacologically stimulable. Several experimental studies have shown that the exogenous administration of cAMP agonists, in particular $\beta 2$-agonists, accelerates the resolution of edema, whatever its nature [85]. A preliminary study [86] showed that the intravenous administration of salbutamol at a dose of $15 \mu \mathrm{g} / \mathrm{kg} / \mathrm{h}$ for 7 days in ARDS patients made possible to diminish the quantity of pulmonary water measured by transpulmonary thermodilution without affecting oxygenation, duration of mechanical ventilation, or outcome. However, the same authors showed in a large RCT involving 326 patients [87] that $15 \mu \mathrm{g} / \mathrm{kg} / \mathrm{h}$ of intravenous salbutamol was poorly tolerated and was associated with an increase in 28-day mortality (34 vs. $23 \%$ in the control group, $p=0.033$ ). Another RCT has evaluated the effect of aerosolized albuterol six times per day until day 10 or extubation in patients with acute lung injury [88]. The study was stopped for futility after the inclusion of 282 patients. The number of ventilatorfree days, which was the primary outcome variable, was not different between groups. These data do not support the use of aerosolized $\beta 2$-agonists to improve outcome in patients with ARDS, and strongly suggest that intravenous salbutamol may worsen outcome in those patients.

\section{Corticosteroids}

Corticosteroids have a broad inhibitory action on host defenses, including inhibition of the transcription of proinflammatory cytokines, inhibition of neutrophil activation, a synergic action with anti-inflammatory cytokines, and a suppression of the synthesis of phospholipase A2, cyclooxygenase, and inducible NO synthase [89]. Because of these properties, corticosteroids in high doses for a short period were proposed in the early phase of ARDS, mostly in septic patients, to obtain a quick resolution and to prevent progression to lung fibrosis.

Four randomized trials investigated early use of high doses of corticosteroids for the prevention of ARDS in septic shock patients [90-92] or in patients with confirmed ARDS [93]. In these studies, corticosteroids significantly reduced the duration of mechanical ventilation. However, these studies showed no benefit in terms of prevention or improvement of ARDS and no effect or even an increase of mortality with corticosteroids. Only relevant ARDS etiologies (pneumocystis pneumonia, pulmonary eosinophilic pneumonia associated with certain autoimmune diseases, or a systemic disease) are recognized as eligible for steroids in the early stages. However, some authors argue that the failure of steroids is not related to their early use but to a too short administration [94]. Corticosteroids have an inhibitory effect on fibroblast proliferation and collagen deposition, including in the lung. Therefore, they were proposed in the late phase of fibroproliferation and post-aggressive fibrosis. Several case reports and a small, randomized study suggested an interest in terms of reduced mortality [95]. This study, although on a small number of patients and despite methodological bias has long been the benchmark to justify corticosteroids in persistent ARDS.

More recently, another RCT by Meduri evaluated early corticosteroid administration, and showed that methylprednisolone administration $(1 \mathrm{mg} / \mathrm{kg} / \mathrm{d})$ less than 72 after the onset of ARDS reduced mortality [96]. However, these results should be interpreted with caution, because this study included a large number of patients with septic shock. Another randomized, controlled trial, conducted by the ARDS network, showed no reduction in mortality in the group receiving methylprednisolone [44]. This study involved 180 patients with ARDS persistent after 7 to 28 days who received methylprednisolone $(2 \mathrm{mg} / \mathrm{kg} / \mathrm{d})$ or placebo for 21 days. The protocol used was borrowed from corticosteroid Meduri study [95] and also is the protocol commonly used in clinical practice. Despite the lack of benefit in terms of mortality at 60 days, an increased $\mathrm{PaO}_{2}$ to $\mathrm{FiO}_{2}$ ratio and thoracopulmonary compliance were found in the group receiving corticosteroids, as well as shorter durations of mechanical ventilation and ICU stay. The subgroup analysis showed a significantly higher mortality rate when corticosteroid therapy was started after the 13th day of ARDS, suggesting the presence of fixed fibrotic lesions at this stage, at the expense of a steroid-sensitive fibroproliferation. However, this study had some bias, including a very important initial selection (5\% of eligible patients included) with an only $30 \%$ mortality rate in persistent ARDS, a brutal discontinuation of steroids after 48 hours of ventilator weaning and finally the absence of pathologic analysis leading probably to a treatment with corticosteroids in some patients without fibroproliferation. The subgroup analysis suggests this hypothesis. Indeed, patients with a low level of procollagen III in their alveolar lavage fluid, thus having a lesser degree of fibroproliferation, had a higher mortality if they had received steroids (35\% vs. 9\%, $p<0.05$ ) [44]. On the other hand, it is conceivable that some of them were carrying a contraindication to steroids because of an infection. 
Papazian et al. [97] recently showed that only 53\% of persistent ARDS patients actually had fibrosis or fibroproliferation highlighted on surgical biopsies and that more than half of them had an infectious contraindication to systemic corticosteroids, notably because they presented with an untreated infection. Conflicting data exist on the interest of low doses of corticosteroids (200 mg/day of hydrocortisone) in ARDS patients. A post hoc analysis [98] of an RCT of low doses of steroids in septic shock patients [99] noted that mortality was improved mainly in the subgroup of patients with ARDS and no response to corticotrophin stimulation. On the other hand, two recent studies suggested that early treatment with low doses of corticosteroids was inefficient or even harmful in patients with H1N1 pneumonia [100] or ARDS [101]. Further randomized, controlled trials are needed before any definitive conclusion.

In the context of a persistent ARDS with histological proof of fibroproliferation, a corticosteroid treatment can be proposed according to the protocol by Meduri et al., with a progressive decrease of doses [95]. This protocol is accompanied by measures usually applied in case of prolonged corticosteroid therapy (gastric protection, prevention of electrolyte disorders, treatment of diabetes, restriction of the use of NMBs) to which can be added a systematic bacteriological monitoring supplemented by other sampling in case of suspicion of infection. One of the main complications of corticosteroid treatment is ICU acquired weakness [54,55], potentially reversible but often leading to difficulties in weaning from ventilation.

\section{Conclusions}

The place of iNO as a rescue therapy has been clarified by numerous studies that gave practical guidelines on its use. The modest reduction of ventilation duration obtained with a conservative fluid strategy for patients who do not have evidence of tissue hypoperfusion makes impossible to create a "gold standard" for management of the fluid status of every ARDS patient. Further studies must confirm recent data from the literature, which provide a strong argument for beneficial effects of NMBs during the early phase of severe ARDS. Concerning corticosteroids, numerous questions remain on their potential benefits in subgroups of ARDS patients. Finally, current and future research has to consider the interest of therapeutics designed to reduce lung inflammation and to enhance alveolar repair. Some of the promising research areas include cell-based therapy with mesenchymal stem cells, which could reverse the major abnormalities of lung injury [102], statin therapy [103], anti-inflammatory drugs, such as aspirin [104], or the modulation of signaling pathway of proteins involved in the regulation of vascular permeability $[105,106]$.

\section{Competing interests}

The authors declare no conflict of interest that may inappropriately influence how results are presented in this paper.

\section{Authors' contributions}

AR, SH, SD, and LP drafted the manuscript. All authors read and approved the final manuscript

\section{Author details}

'URMITE, UM63, CNRS 7278, Aix Marseille Université, IRD 198, Inserm 1095, 13005, Marseille, France. ${ }^{2}$ APHM, CHU Nord, Réanimation, 13015, Marseille, France. ${ }^{3}$ Intensive Care Unit, CHU Nord, Chemin des Bourrely, 13015, Marseille, France.

Received: 5 April 2013 Accepted: 14 June 2013

Published: 3 July 2013

\section{References}

1. Matthay MA, Ware $L B$, Zimmerman GA: The acute respiratory distress syndrome. J Clin Invest 2012, 122:2731-2740.

2. The ARDS Definition Task Force: Acute respiratory distress syndrome: the Berlin definition. JAMA 2012, 307:2526-2533.

3. Rossaint R, Falke KJ, Lopez F, Slama K, Pison U, Zapol WM: Inhaled nitric oxide for the adult respiratory distress syndrome. N Eng J Med 1993, 328:399-405.

4. Taylor RW, Zimmerman JL, Dellinger RP, Straube RC, Criner GJ, Davis K Jr, Kelly KM, Smith TC, Small RJ: Low-dose inhaled nitric oxide in patients with acute lung injury: a randomized controlled trial. JAMA 2004, 291:1603-1609.

5. Michael JR, Barton RG, Saffle JR, Mone M, Markewitz BA, Hillier K, Elstad MR, Campbell EJ, Troyer BE, Whatley RE, Liou TG, Samuelson WM, Carveth HJ, Hinson DM, Morris SE, Davis BL, Day RW: Inhaled nitric oxide versus conventional therapy: effect on oxygenation in ARDS. Am J Respir Crit Care Med 1998, 157:1372-1380.

6. Dellinger RP, Zimmerman JL, Taylor RW, Straube RC, Hauser DL, Criner GJ, Davis K Jr, Hyers TM, Papadakos P: Effects of inhaled nitric oxide in patients with acute respiratory distress syndrome: results of a randomized phase II trial. Crit Care Med 1998, 26:15-23.

7. Troncy E, Collet JP, Shapiro S, Guimond JG, Blair L, Ducruet T, Francoeur M, Charbonneau M, Blaise G: Inhaled nitric oxide in acute respiratory distress syndrome: a pilot randomized controlled study. Am J Respir Crit Care Med 1998, 157:1483-1488.

8. Lundin S, Mang H, Smithies M, Stenqvist O, Frostell C, The European Study Group of Inhaled Nitric Oxide: Inhalation of nitric oxide in acute lung injury: results of a European multicentre study. Intensive Care Med 1999, 25:911-919.

9. Adhikari NK, Burns KE, Friedrich JO, Granton JT, Cook DJ, Meade MO: Effect of nitric oxide on oxygenation and mortality in acute lung injury: systematic review and metaanalysis. BMJ 2007, 334:779.

10. Germann P, Braschi A, Della Rocca G, Dinh-Xuan AT, Falke K, Frostell C, Gustafsson LE, Hervé $P$, Jolliet $P$, Kaisers U, Litvan H, Macrae DJ, Maggiorini M, Marczin N, Mueller B, Payen D, Ranucci M, Schranz D, Zimmermann R, Ullrich R: Inhaled nitric oxide therapy in adults: European expert recommendations. Intensive Care Med 2005, 31:1029-1041.

11. Papazian L, Forel JM, Gacouin A, Penot-Ragon C, Perrin G, Loundou A, Jaber S, Arnal JM, Perez D, Seghboyan JM, Constantin JM, Courant P, Lefrant JY, Guérin C, Prat G, Morange S, Roch A, ACURASYS Study Investigators: Neuromuscular blockers in early acute respiratory distress syndrome. $N$ Engl J Med 2010, 363:1107-1116.

12. Mercat A, Richard JC, Vielle B, Jaber S, Osman D, Diehl JL, Lefrant JY, Prat G, Richecoeur J, Nieszkowska A, Gervais C, Baudot J, Bouadma L, Brochard L, Expiratory Pressure (Express) Study Group: Positive end-expiratory pressure setting in adults with acute lung injury and acute respiratory distress syndrome: a randomized controlled trial. JAMA 2008, 299:646-655.

13. Davies A, Jones D, Bailey M, Beca J, Bellomo R, Blackwell N, Forrest P, Gattas D, Granger E, Herkes R, Jackson A, McGuinness S, Nair P, Pellegrino V, Pettilä V, Plunkett B, Pye R, Torzillo P, Webb S, Wilson M, Ziegenfuss M: Extracorporeal membrane oxygenation for 2009 influenza $A(H 1 N 1)$ acute respiratory distress syndrome. JAMA 2009, 302:1888-1895.

14. Christenson J, Lavoie A, O'Connor M, Bhorade S, Pohlman A, Hall JB: The incidence and pathogenesis of cardiopulmonary deterioration after abrupt withdrawal of inhaled nitric oxide. Am J Respir Crit Care Med 2000, 161:1443-1449. 
15. Brett SJ, Hansell DM, Evans TW: Clinical correlates in acute lung injury: response to inhaled nitric oxide. Chest 1998, 114:1397-1404.

16. Rossaint R, Gerlach H, Schmidt-Ruhnke H, Pappert D, Lewandowski K, Steudel W: Efficacy of inhaled nitric oxide in patients with severe ARDS. Chest 1995, 107:1107-1115.

17. Puybasset L, Rouby JJ, Mourgeon E, Stewart TE, Cluzel P, Arthaud M, Poète $P$, Bodin L, Korinek AM, Viars P: Inhaled nitric oxide in acute respiratory failure: dose-response curves. Intensive Care Med 1994, 20:319-327.

18. Gerlach H, Rossaint R, Pappert D, Falke KJ: Time-course and dose-response of nitric oxide inhalation for systemic oxygenation and pulmonary hypertension in patients with adult respiratory distress syndrome. Eur J Clin Invest 1993, 23:499-502.

19. Hsu CW, Lee DL, Lin SL, Sun SF, Chang HW: The initial response to inhaled nitric oxide treatment for intensive care unit patients with acute respiratory distress syndrome. Respiration 2008, 75:288-295.

20. Gerlach H, Keh D, Semmerow A, Busch T, Lewandowski K, Pappert DM, Rossaint $\mathrm{R}$, Falke $\mathrm{KJ}$ : Dose-response characteristics during long-term inhalation of nitric oxide in patients with severe acute respiratory distress syndrome: a prospective, randomized, controlled study. Am J Respir Crit Care Med 2003, 167:1008-1015.

21. Papazian L, Bregeon F, Gaillat F, Thirion X, Gainnier M, Gregoire R, Saux P, Gouin F, Jammes $Y$, Auffray JP: Respective and combined effects of prone position and inhaled nitric oxide in patients with acute respiratory distress syndrome. Am J Respir Crit Care Med 1998, 157:580-585.

22. Mehta S, MacDonald R, Hallett DC, Lapinsky SE, Aubin M, Stewart TE: Acute oxygenation response to inhaled nitric oxide when combined with high-frequency oscillatory ventilation in adults with acute respiratory distress syndrome. Crit Care Med 2003, 31:383-389.

23. Papazian L, Bregeon F, Gaillat F, Thirion X, Roch A, Cortes E, Fulachier V, Saux P, Jammes $Y$, Auffray JP: Inhaled NO and almitrine bismesylate in patients with acute respiratory distress syndrome: effect of noradrenalin. Eur Respir J 1999, 14:1283-1289.

24. Papazian L, Bregeon F, Gaillat F, Kaphan E, Thirion X, Saux P, Badier M, Gregoire R, Gouin F, Jammes Y, Auffray JP: Does norepinephrine modify the effects of inhaled nitric oxide in septic patients with acute respiratory distress syndrome? Anesthesiology 1998, 89:1089-1098.

25. Papazian L, Roch A, Bregeon F, Thirion X, Gaillat F, Saux P, Fulachier V, Jammes $Y$, Auffray JP: Inhaled nitric oxide and vasoconstrictors in acute respiratory distress syndrome. Am J Respir Crit Care Med 1999, $160: 473-479$

26. Roch A, Papazian L, Bregeon F, Gainnier M, Michelet P, Thirion X, Saux P, Thomas $P$, Jammes $Y$, Auffray JP: High or low doses of almitrine bismesylate in ARDS patients responding to inhaled NO and receiving norepinephrine? Intensive Care Med 2001, 27:1737-1743.

27. Griffiths MJ, Evans TW: Inhaled nitric oxide therapy in adults. N Engl J Med 2005, 353:2683-2695

28. Cuthbertson BH, Dellinger P, Dyar OJ, Evans TE, Higenbottam T, Latimer R, Payen D, Stott SA, Webster NR, Young J: UK guidelines for the use of inhaled nitric oxide therapy in adult ICUs: American- European Consensus Conference on ALI/ARDS. Intensive Care Med 1997, 23:1212-1218.

29. Westfelt UN, Lundin S, Stenqvist O: Nitric oxide administration after the ventilator: evaluation of mixing conditions. Acta Anaesthesio/ Scand 1997, 41:266-273

30. Young JD, Dyar O, Xiong L, Howell S: Methaemoglobin production in normal adults inhaling low concentrations of nitric oxide. Intensive Care Med 1994, 20:581-584

31. Naeije R, Lejeune P, Vachiery JL, Leeman M, Melot C, Hallemans R, Delcroix M, Brimioulle $\mathrm{S}$ : Restored hypoxic pulmonary vasoconstriction by peripheral chemoreceptor agonists in dogs. Am Rev Respir Dis 1990, 142:789-795.

32. Reyes A, Roca J, Rodriguez_Roisin R, Torres A, Ussetti P, Wagner PD: Effect of almitrine on ventilation-perfusion distribution in adult respiratory distress syndrome. Am Rev Respir Dis 1988, 137:1062-1067.

33. Wysocki M, Delclaux C, Roupie E, Langeron O, Liu N, Herman B, Lemaire F, Brochard $L$ : Additive effect on gas exchange of inhaled nitric oxide and intravenous almitrine bismesylate in the adult respiratory distress syndrome. Intensive Care Med 1994, 20:254-259.

34. Lu Q, Mourgeon E, Law_Koune JD, Roche S, Vezinet C, Abdennour L, Vicaut E, Puybasset L, Diaby M, Coriat P: Dose-response curves of inhaled nitric oxide with and without intravenous almitrine in nitric oxide-responding patients with acute respiratory distress syndrome. Anesthesiology 1995, 83:929-943.
35. Gillart T, Bazin JE, Cosserant B, Guelon D, Aigouy L, Mansoor O, Schoeffler P: Combined nitric oxide inhalation, prone positioning and almitrine infusion improve oxygenation in severe ARDS. Can J Anaesth 1998, 45:402-409.

36. Gottschall EB, Fernyak S, Wuertemberger G, Voelkel NF: Almitrine mimics hypoxic vasoconstriction in isolated rat lungs. Am J Physiol 1992, 263:H383-H391.

37. Russell PC, Emery CJ, Nicholl J, Barer GR, Howard P: Interactions between hypoxic and almitrine-induced vasoconstriction in the rat lung. Clin Sci 1992, 82:265-272.

38. Gallart L, Lu Q, Puybasset L, Umamaheswara Rao GS, Coriat P, Rouby JJ: Intravenous almitrine combined with inhaled nitric oxide for acute respiratory distress syndrome. The NO Almitrine Study Group. Am J Resp Crit Care Med 1998, 158:1770-1777.

39. Sommerer A, Kaisers U, Dembinski R, Bubser HP, Falke KJ, Rossaint R: Dose-dependent effects of almitrine on hemodynamics and gas exchange in an animal model of acute lung injury. Intensive Care Med 2000, 26:434-441

40. Michard F, Wolff M, Herman B, Wysocki M: Right ventricular response to high-dose almitrine infusion in patients with severe hypoxemia related to acute respiratory distress syndrome. Crit Care Med 2001, 29:32-36

41. Gherardi R, Baudrimont M, Gray F, Louarn F: Almitrine neuropathy. A nerve biopsy study of 8 cases. Acta Neuropathol 1987, 73:202-208.

42. Bouche $P$, Lacomblez $L$, Leger JM, Chaunu MP, Ratinahirana $H$, Brunet $P$, Hauw JJ, Cathala HP, Laplane D: Peripheral neuropathies during treatment with almitrine: report of 46 cases. J Neurol 1989, 236:29-33.

43. Bchir A, Mebazaa A, Losser MR, Romieu M, Payen D: Intravenous almitrine bismesylate reversibly induces lactic acidosis and hepatic dysfunction in patients with acute lung injury. Anesthesiology 1998, 89:823-830.

44. Steinberg KP, Hudson LD, Goodman RB, Hough CL, Lanken PN, Hyzy R, Thompson BT, Ancukiewicz M, National Heart, Lung, and Blood Institute Acute Respiratory Distress Syndrome (ARDS) Clinical Trials Network: Efficacy and safety of corticosteroids for persistent acute respiratory distress syndrome. N Engl J Med 2006, 354:1671-1684

45. Brower RG, Lanken PN, Maclntyre N, Matthay MA, Morris A, Ancukiewicz M, Schoenfeld D, Thompson BT, National Heart, Lung, and Blood Institute ARDS Clinical Trials Network: Higher versus lower positive end-expiratory pressures in patients with the acute respiratory distress syndrome. N Engl J Med 2004, 351:327-336.

46. Arroliga AC, Thompson BT, Ancukiewicz M, Gonzales JP, Guntupalli KK, Park PK, Wiedemann HP, Anzueto A, Acute Respiratory Distress Syndrome Network: Use of sedatives, opioids, and neuromuscular blocking agents in patients with acute lung injury and acute respiratory distress syndrome. Crit Care Med 2008, 36:1083-1088.

47. Mehta S, Granton J, MacDonald RJ, Bowman D, Matte-Martyn A, Bachman T, Smith T, Stewart TE: High-frequency oscillatory ventilation in adults: the Toronto experience. Chest 2004, 126:518-527.

48. Lagneau F, D'honneur G, Plaud B, Mantz J, Gillart T, Duvaldestin P, Marty J, Clyti N, Pourriat $\mathrm{J}$ : A comparison of two depths of prolonged neuromuscular blockade induced by cisatracurium in mechanically ventilated critically ill patients. Intensive Care Med 2002, 28:1735-1741.

49. Gainnier M, Roch A, Forel JM, Thirion X, Arnal JM, Donati S, Papazian L: Effect of neuromuscular blocking agents on gas exchange in patients presenting with acute respiratory distress syndrome. Crit Care Med 2004, 32:113-119.

50. Forel JM, Roch A, Marin V, Michelet P, Demory D, Blache JL, Perrin G, Gainnier M, Bongrand P, Papazian L: Neuromuscular blocking agents decrease inflammatory response in patients presenting with acute respiratory distress syndrome. Crit Care Med 2006, 34:2749-2757.

51. Neto AS, Pereira VG, Espósito DC, Damasceno MC, Schultz MJ: Neuromuscular blocking agents in patients with acute respiratory distress syndrome: a summary of the current evidence from three randomized controlled trials. Ann Intensive Care 2012, 2:33.

52. Slutsky AS: Neuromuscular blocking agents in ARDS. N Engl J Med 2010, 363:1176-1180.

53. Yoshida T, Uchiyama A, Matsuura N, Mashimo T, Fujino Y: Spontaneous breathing during lung-protective ventilation in an experimental acute lung injury model: high transpulmonary pressure associated with strong spontaneous breathing effort may worsen lung injury. Crit Care Med 2012, 40:1578-1585.

54. Latronico N, Bolton CF: Critical illness polyneuropathy and myopathy: a major cause of muscle weakness and paralysis. Lancet Neurol 2011, 10:931-941. 
55. De Jonghe B, Lacherade JC, Sharshar T, Outin H: Intensive care unit-acquired weakness: risk factors and prevention. Crit Care Med 2009, 37:S309-S315.

56. Griffiths RD, Hall JB: Intensive care unit-acquired weakness. Crit Care Med 2010, 38:779-787.

57. Dong SW, Mertes PM, Petitpain N, Hasdenteufel F, Malinovsky JM, GERAP: Hypersensitivity reactions during anesthesia. Results from the ninth French survey (2005-2007). Minerva Anestesiol 2012, 78:8688-78.

58. Hardin KA, Seyal M, Stewart T, Bonekat HW: Sleep in critically ill chemically paralyzed patients requiring mechanical ventilation. Chest 2006 129:1468-1477.

59. Rivers E, Nguyen B, Havstad S, Ressler J, Muzzin A, Knoblich B, Peterson E, Tomlanovich M, Early Goal-Directed Therapy Collaborative Group: Early goal-directed therapy in the treatment of severe sepsis and septic shock. N Engl J Med 2001, 345:1368-1377.

60. Stapleton RD, Wang BM, Hudson LD, Rubenfeld GD, Caldwell ES, Steinberg KP: Causes and timing of death in patients with ARDS. Chest 2005, 128:525-532.

61. Roch A, Guervilly C, Papazian L: Fluid management in acute lung injury and ards. Ann Intensive Care 2011, 1:16.

62. Sakka SG, Klein M, Reinhart K, Meier-Hellmann A: Prognostic value of extravascular lung water in critically ill patients. Chest 2002, 122:2080-2086.

63. Phillips CR, Chesnutt MS, Smith SM: Extravascular lung water in sepsis-associated acute respiratory distress syndrome: indexing with predicted body weight improves correlation with severity of illness and survival. Crit Care Med 2008, 36:69-73.

64. Jozwiak M, Silva S, Persichini R, Anguel N, Osman D, Richard C, Teboul JL, Monnet $X$ : Extravascular lung water is an independent prognostic factor in patients with acute respiratory distress syndrome. Crit Care Med 2013, 41:472-480

65. Sakr Y, Vincent JL, Reinhart K, Groeneveld J, Michalopoulos A, Sprung CL, Artigas A, Ranieri VM, Sepsis Occurence in Acutely III Patients Investigator: High tidal volume and positive fluid balance are associated with worse outcome in acute lung injury. Chest 2005, 128:3098-3108.

66. Boyd JH, Forbes J, Nakada TA, Walley KR, Russell JA: Fluid resuscitation in septic shock: a positive fluid balance and elevated central venous pressure are associated with increased mortality. Crit Care Med 2011, 39:259-265.

67. Wiedemann HP, Wheeler AP, Bernard GR, Thompson BT, Hayden D, de Boisblanc B, Connors AF Jr, Hite RD, Harabin AL: Comparison of two fluid-management strategies in acute lung injury. N Engl J Med 2006, 354:2564-2575.

68. Rivers EP: Fluid-management strategies in acute lung injury-liberal, conservative, or both? N Engl J Med 2006, 354:2598-2600.

69. Murphy CV, Schramm GE, Doherty JA, Reichley RM, Gajic O, Afessa B, Micek ST, Kollef $\mathrm{MH}$ : The importance of fluid management in acute lung injury secondary to septic shock. Chest 2009, 136:102-109.

70. Dellinger RP, Levy MM, Rhodes A, Annane D, Gerlach H, Opal SM, Sevransky JE, Sprung CL, Douglas IS, Jaeschke R, Osborn TM, Nunnally ME, Townsend SR, Reinhart K, Kleinpell RM, Angus DC, Deutschman CS, Machado FR, Rubenfeld GD, Webb S, Beale RJ, Vincent JL, Moreno R, Surviving Sepsis Campaign Guidelines Committee including The Pediatric Subgroup: Surviving sepsis campaign: international guidelines for management of severe sepsis and septic shock, 2012. Intensive Care Med 2013, 39:165-228.

71. Guyton AC: Interstitial fluid pressure. II. Pressure-volume curves of interstitial space. Circ Res 1965, 16:452-460.

72. Prewitt RM, McCarthy J, Wood LD: Treatment of acute low pressure pulmonary edema in dogs: relative effects of hydrostatic and oncotic pressure, nitroprusside, and positive end expiratory pressure. J Clin Invest 1981, 67:409-418.

73. Martin GS, Mangialardi RJ, Wheeler AP, Dupont WD, Morris JA, Bernard GR: Albumin and furosemide therapy in hypoproteinemic patients with acute lung injury. Crit Care Med 2002, 30:2175-2182.

74. Martin GS, Moss M, Wheeler AP, Mealer M, Morris JA, Bernard GR: A randomized, controlled trial of furosemide with or without albumin in hypoproteinemic patients with acute lung injury. Crit Care Med 2005, 33:1681-1687.

75. Finfer S, Bellomo R, Boyce N, French J, Myburgh J, Norton R: A comparison of albumin and saline for fluid resuscitation in the intensive care unit. N Engl J Med 2004, 350:2247-2256.

76. Charpentier J, Mira JP, EARSS study group: Efficacy and tolerance of hyperocotic albumin administration in septic shock patients: the EARSS study. Intensive Care Med 2012, 37:S115.
77. Gattinoni L: Albumin in Severe Sepsis and Septic Shock: the ALBIOS Study. Lisbon: ESICM Lives 2012 Lisbon, 25th annual congress; 2012:201. 13-17 October 2012. Session fluid therapy in septic shock.

78. Myburgh JA, Finfer S, Bellomo R, Billot L, Cass A, Gattas D, Glass P, Lipman J, Liu B, McArthur C, McGuinness S, Rajbhandari D, Taylor CB, Webb SA: Hydroxyethyl starch or saline for fluid resuscitation in intensive care. N Engl J Med 2012, 367:1901-1911.

79. Perner A, Haase N, Guttormsen AB, Tenhunen J, Klemenzson G, Åneman A Madsen KR, Møller MH, Elkjær JM, Poulsen LM, Bendtsen A, Winding R, Steensen M, Berezowicz P, Søe-Jensen P, Bestle M, Strand K, Wiis J, White JO, Thornberg KJ, Quist L, Nielsen J, Andersen LH, Holst LB, Thormar K, Kjældgaard AL, Fabritius ML, Mondrup F, Pott FC, Møller TP, Winkel P, Wetterslev J: Hydroxyethyl starch 130/0.42 versus Ringer's acetate in severe sepsis. N Engl J Med 2012, 367:124-134.

80. Homma H, Deitch EA, Feketeova E, Lu Q, Berezina TL, Zaets SB, Machiedo GW, Xu DZ: Small volume resuscitation with hypertonic saline is more effective in ameliorating trauma-hemorrhagic shock-induced lung injury, neutrophil activation and red blood cell dysfunction than pancreatitic protease inhibition. J Trauma 2005, 59:266-272.

81. Roch A, Blayac D, Ramiara P, Chetaille B, Marin V, Michelet P, Lambert D, Papazian L, Auffray JP, Carpentier JP: Comparison of lung injury after normal or small volume optimized resuscitation in a model of hemorrhagic shock. Intensive Care Med 2007, 33:1645-1654.

82. Roch A, Castanier M, Mardelle V, Trousse D, Marin V, Avaro JP, Tasei AM, Blayac $D$, Michelet P, Fusai T, Papazian L: Effect of hypertonic saline pre-treatment on ischemia-reperfusion lung injury in pig. J Heart Lung Transplant 2008, 27:1023-1030.

83. Bulger EM, May S, Kerby JD, Emerson S, Stiell IG, Schreiber MA, Brasel KJ, Tisherman SA, Coimbra R, Rizoli S, Minei JP, Hata JS, Sopko G, Evans DC, Hoyt DB: Out-of-hospital hypertonic resuscitation after traumatic hypovolemic shock: a randomized, placebo controlled trial. Ann Surg 2011, 253:431-441.

84. Ware LB, Matthay MA: Alveolar fluid clearance is impaired in the majority of patients with acute lung injury and the acute respiratory distress syndrome. Am J Respir Crit Care Med 2001, 163:1376-1383.

85. Mehta D, Bhattacharya J, Matthay MA, Malik AB: Integrated control of lung fluid balance. Am J Physiol Lung Cell Mol Physiol 2004, 287:L1081-L1090.

86. Perkins GD, McAuley DF, Thickett DR, Gao F: The beta agonist lung injury trial (BALTI): a randomised placebo-controlled clinical trial. Am J Respir Crit Care Med 2006, 173:281-287.

87. Gao Smith F, Perkins GD, Gates S, Young D, McAuley DF, Tunnicliffe W, Khan Z, Lamb SE, BALTI-2 study investigators: Effect of intravenous $\beta$-2 agonist treatment on clinical outcomes in acute respiratory distress syndrome (BALTI-2): a multicentre, randomised controlled trial. Lancet 2012, 379:229-235.

88. Matthay MA, Brower RG, Carson S, Douglas IS, Eisner M, Hite D, Holets S, Kallet $\mathrm{RH}$, Liu KD, Maclntyre N, Moss M, Schoenfeld D, Steingrub J, Thompson BT: Randomized, placebo-controlled clinical trial of an aerosolized $\beta_{2}$-agonist for treatment of acute lung injury. Am J Respir Crit Care Med 2011, 184:561-568.

89. Thompson BT: Glucocorticoids and acute lung injury. Crit Care Med 2003, 31:253-257.

90. Sprung CL, Caralis PV, Marcial EH, Pierce M, Gelbard MA, Long WM, Duncan $\mathrm{RC}$, Tendler MD, Karpf M: The effect of high dose corticosteroids in patients with septic shock. N Engl J Med 1984, 311:1137-1143.

91. Luce JM, Montgomery AB, Marks JD, Turner J, Metz CA, Murray JF: Ineffectiveness of high dose methylprednisolone in preventing parenchymal lung injury and improving mortality in patients with septic shock. Am Rev Respir Dis 1988, 138:62-68.

92. Weigelt JA, Norcross JF, Borman KR, Snyder WH 3rd: Early steroid therapy for respiratory failure. Arch Surg 1985, 120:536-540.

93. Bernard GB, Luce JM, Sprung CL: High dose corticosteroids in patients with the adult respiratory distress syndrome. N Engl J Med 1987, 317:1565-1570.

94. Meduri GU, Carratu P, Freire AX: Evidence of biological efficacy for prolonged glucocorticoid treatment in patients with unresolving ARDS. Eur Respir J 2003, 22:57-64.

95. Meduri GU, Headley AS, Golden E, Carson SJ, Umberger RA, Kelso T, Tolley EA: Effect of prolonged methylprednisolone therapy in unresolving acute respiratory distress syndrome: a randomized controlled trial. JAMA 1998, 280:159-165.

96. Meduri GU, Golden E, Freire AX, Taylor E, Zaman M, Carson SJ, Gibson M, Umberger R: Methylprednisolone infusion in early severe ARDS results of a randomized controlled trial. Chest 2009, 136:e30. 
97. Papazian L, Doddoli C, Chetaille B, Gernez Y, Thirion X, Roch A, Donati Y, Bonnety M, Zandotti C, Thomas P: A contributive result of open-lung biopsy improves survival in acute respiratory distress syndrome patients. Crit Care Med 2007, 35:755-762.

98. Annane D, Sébille V, Bellissant E, Ger-Inf-05 Study Group: Effect of low doses of corticosteroids in septic shock patients with or without early acute respiratory distress syndrome. Crit Care Med 2006, 34:22-30.

99. Annane D, Sébille V, Charpentier C, Bollaert PE, François B, Korach JM, Capellier G, Cohen Y, Azoulay E, Troché G, Chaumet-Riffaud P, Bellissant E: Effect of treatment with low doses of hydrocortisone and fludrocortisone on mortality in patients with septic shock. JAMA 2002, 288:862-871.

100. Kim SH, Hong SB, Yun SC, Choi WI, Ahn JJ, Lee YJ, Lee HB, Lim CM, Koh Y, Korean Society of Critical Care Medicine H1N1 Collaborative: Corticosteroid treatment in critically ill patients with pandemic influenza A/H1N1 2009 infection: analytic strategy using propensity scores. Am J Respir Crit Care Med 2011, 183:1207-1214.

101. Brun-Buisson C, Richard JC, Mercat A, Thiébaut AC, Brochard L, REVA-SRLF A/H1N1v 2009 Registry Group: Early corticosteroids in severe influenza A/H1N1 pneumonia and acute respiratory distress syndrome. Am J Respir Crit Care Med 2011, 183:1200-1206.

102. Matthay MA, Thompson BT, Read EJ, McKenna DH Jr, Liu KD, Calfee CS, Lee JW: Therapeutic potential of mesenchymal stem cells for severe acute lung injury. Chest 2010, 138:965-972.

103. De Loecker I, Preiser JC: Statins in the critically ill. Ann Intensive Care 2012, 2:19.

104. Looney MR, Nguyen JX, Hu Y, Van Ziffle JA, Lowell CA, Matthay MA: Platelet depletion and aspirin treatment protect mice in a two-event model of transfusion-related acute lung injury. J Clin Invest 2009, 119:3450-3461.

105. Lee WL, Slutsky AS: Sepsis and endothelial permeability. N Engl J Med 2010, 363:689-691.

106. London NR, Zhu W, Bozza FA, Smith MC, Greif DM, Sorensen LK, Chen L, Kaminoh Y, Chan AC, Passi SF, Day CW, Barnard DL, Zimmerman GA, Krasnow MA, Li DY: Targeting Robo4-dependent slit signaling to survive the cytokine storm in sepsis and influenza. Sci Transl Med 2010, 2:23ra19.

doi:10.1186/2110-5820-3-20

Cite this article as: Roch et al:: Pharmacological interventions in acute respiratory distress syndrome. Annals of Intensive Care 2013 3:20.

\section{Submit your manuscript to a SpringerOpen ${ }^{\circ}$ journal and benefit from:}

- Convenient online submission

- Rigorous peer review

- Immediate publication on acceptance

- Open access: articles freely available online

- High visibility within the field

- Retaining the copyright to your article

Submit your next manuscript at $\gg$ springeropen.com 